\title{
PHYSIOLOGICAL RELATIONSHIPS IN Aleurites fordii Hemsl. SEEDLINGS ${ }^{1}$
}

\author{
Braulio Otomar Caron ${ }^{2}$, Julia Renata Schneider ${ }^{3}$, Elvis Felipe Elli ${ }^{*}$, Elder Eloy ${ }^{5}$ and Velci Queiróz de \\ Souza $^{2}$
}

\begin{abstract}
${ }^{1}$ Received on 09.05.2014 accepted for publication on 11.11.2016.
${ }^{2}$ Universidade Federal de Santa Maria, Campus de Frederico Westphalen, Departamento de Ciências Agronômicas e Ambientais, Frederico Westphalen, RS - Brasil.E-mail: <otomarcaron@yahoo.com.br> and <velciq@smail.ufsm.br>.

${ }^{3}$ Universidade Federal de Santa Maria, Graduanda em Agronomia, Frederico Westphalen, RS - Brasil. E-mail: $<$ juliaschneider07@hotmail.com>.

${ }^{4}$ Universidade Federal de Santa Maria, Campus de Frederico Westphalen, Programa de Pós Graduação em Agronomia, Agricultura e Ambiente, Frederico Westphalen, RS - Brasil. E-mail: <elvisfelipeelli@yahoo.com>.

${ }^{5}$ Universidade Federal de Santa Maria, Campus de Frederico Westphalen, Departamento de Engenharia Florestal, Frederico Westphalen, RS - Brasil. E-mail: <eloyelder@yahoo.com.br>.

*Corresponding author.
\end{abstract}

\begin{abstract}
The objective of this work was to evaluate the physiological behavior at different times of the day and the level of dependence between physiological variables and meteorological elements in Aleurites fordii seedlings. The experiment was conducted in a greenhouse, using a completely randomized experimental design, in a uniform scheme composed of 10 evaluation times (from 8 am to $5 \mathrm{pm}$, with an interval of $1 \mathrm{~h}$ between evaluations) and three replications. Each replicate consisted of three evaluation plants, totaling nine seedlings, which were arranged on a double border. The following characteristics were evaluated: leaf temperature $\left({ }^{\circ} \mathrm{C}\right)$, photosynthetically active solar radiation $\left(\mu \mathrm{mol} \mathrm{S}^{-1} \mathrm{~m}^{-2}\right)$, stomatal resistance $\left(\mathrm{S} \mathrm{cm}^{-1}\right)$, and transpiration $(\mathrm{mmol}$ $\mathrm{H}_{2} \mathrm{O} \mathrm{s}^{-1} \mathrm{~m}^{-2}$ ) over a typical day, using a LI-1600 LI-COR digital porometer. The temperature and relative humidity were measured inside the greenhouse, using a thermohygrograph. The evaluations were performed at 244 days after sowing, between 8:00 and 17:00, with an interval of 60 minutes, totaling 10 evaluations. The physiological changes of Aleurites fordii seedlings are affected by the time of day. In general, the physiological variables are highly dependent on meteorological elements. The temperature of the greenhouse and the relative humidity are the meteorological elements that most influence the physiological behavior of Aleurites fordii seedlings.
\end{abstract}

Keywords: Transpiration; Stomata; Photosynthetically active solar radiation.

\section{RELAÇÕES FISIOLÓGICAS EM MUDAS DE Aleurites fordii Hemsl.}

RESUMO - O trabalho teve como objetivo avaliar o comportamento fisiológico em diferentes horários do dia e o nível de dependência entre variáveis fisiológicas e elementos meteorológicos em mudas de Aleurites fordii. O experimento foi conduzido em casa de vegetação, utilizando-se delineamento experimental inteiramente casualizado, em esquema unifatorial composto por 10 horários de avaliação (das 8 às 17h, com intervalo de 1 h entre as avaliações) e três repetições. Cada repetição era constituída por três plantas de avaliação, totalizando nove mudas, as quais estavam dispostas sobre bordadura dupla. Foram avaliadas as características: temperatura da folha $\left({ }^{\circ} \mathrm{C}\right)$, radiação solar fotossinteticamente ativa (imol $\left.\mathrm{S}^{-1} \mathrm{~m}^{-2}\right)$, resistência estomática $\left(\mathrm{S} \mathrm{cm}^{-1}\right)$ e transpiração ( $m$ mol $\mathrm{H}_{2} \mathrm{O} \mathrm{s}^{-1} \mathrm{~m}^{-2}$ ) ao longo de um dia típico, com uso de um porômetro digital LI-1600 LI-COR. As medidas da temperatura e umidade relativa do ar foram determinadas dentro do ambiente protegido, utilizando-se um termohigrógrafo. As avaliações foram realizadas aos 244 dias após a semeadura, entre 8:00 e 17:00h, com intervalo de 60 minutos, totalizando 10 avaliações. O comportamento fisiológico das mudas de Aleurites fordii é afetado pelo horário do dia. De modo geral, as variáveis fisiológicas estudadas são altamente dependentes dos elementos meteorológicos. A temperatura do ambiente protegido e a umidade relativa do ar são os elementos meteorológicos que mais influenciam o comportamento fisiológico das mudas de Aleurites fordii.

Palavras-chave: Transpiração; Estômatos; Radiação fotossinteticamente ativa. 


\section{INTRODUCTION}

Tung (Aleurites fordii Hemsl.) is a deciduous tree plant belonging to the Euphorbiaceae family, which has been highlighted as a focus of studies aimed at its use as an income alternative for small properties, mainly in the southern region of Brazil, the oil extracted from the seeds being used the chemical and paint due to the its fast drying property. It presents little labor demand for its maintenance and occupies agricultural areas not appropriate for annual crops, being that it can be intercropped with other species, and can be considered as a crop that generates opportunity of income insertion (Golfetto et al., 2011; Almeida et al., 2012).

This species, like any other plant, has its growth and development dependent on physiological processes which are controlled by environmental conditions, the intrinsic characteristics of the species and the management practices used (Tonello and Teixeira Filho, 2013). Transpiration and stomatal resistance characterize the water status of the plant (Brunini and Cardoso, 1998; Bergonci et al., 2000; Ribas et al., 2000). For Fagan et al. (2005), the plant organism can maintain an adequate water status, thus modifying its stomatal resistance since water loss is controlled by transpiration. In this same context, Souza et al. (2011) points out that plant transpiration is affected by species, age and other abiotic factors, such as soil type and conditions, meteorological elements and water availability. Thus, in the presence of higher temperatures, transpiration rates tend to be higher.

Studies by Souza et al. (2011) emphasize that the relative humidity of the air, when very low, concomitantly reduces the rates of transpiration and photosynthesis. According to Vellame et al., (2012) in studies related to transpiration, it can be observed that there may be an increase in stomatal resistance when changes in environmental conditions, related to the intensity of solar radiation, differences in vapor pressure in leaves and in the air, which would result in decreased transpiration.

According to Silva et al. (2011), Jatropha curcas $L$. (Barbados nut), from the same family as Aleurites fordii, when in water or saline stress, shows drops in transpiration rates, and consequently in stomatal conductance and photosynthesis rate. Gabriel et al. (2014), in studies on the effects of climatic changes on the Manihot esculenta Crantz (cassava) crop, observed that $\mathrm{CO}_{2}$ assimilation increased when $\mathrm{CO}_{2}$ concentrations were higher in the atmosphere. Therefore, reducing the stomatal opening.

For Melo et al. (2010), studies of physiological parameters such as stomatal resistance are extremely relevant, since they are used to clarify the photosynthetic efficiency of plants through the effects of osmotic and water conditions. Caron et al. (2014), in a study carried out with the species Bauhinia forficata Link (Brazilian orchid tree) showed that the increase of solar radiation causes an increase in leaf temperature and stomatal resistance, while transpiration decreases. In this way, it is observed that when modifying the leaf temperature of the species under study, it ends up in a way modifying the physiological behavior.

In this context, and considering that no studies were found in the literature on the physiological relationships of the species in question, the present study had as objective to evaluate the physiological behavior at different times of the day and the level of dependence between physiological variables and meteorological elements in Aleurites fordii seedlings.

\section{MATERIALAND METHODS}

The experiment was carried out in a greenhouse in the forest nursery of the Federal University of Santa Maria (UFSM), Frederico Westphalen Campus - RS, located at BR 386, Sete de Setembro line, Brazil, whose geographic coordinates are: $27^{\circ} 23^{\prime} 26^{\prime \prime} \mathrm{S}$; $53^{\circ} 25^{\prime} 43^{\prime \prime} \mathrm{W}$ and 641 meters of altitude.

According to Köppen's climatic classification, the climate of the region is Cfa. Frederico Westphalen is approximately $30 \mathrm{~km}$ from Iraí, being the municipality taken as reference for the climatic classification data. As proposed by MALUF (2000), Iraí presents a subhumid undertemperature climate, with an annual average temperature of $18.8^{\circ} \mathrm{C}$ and a mean temperature of the coldest month of $13.3^{\circ} \mathrm{C}$. The average meteorological conditions inside the greenhouse during the evaluation period were: temperature of $39.11^{\circ} \mathrm{C}$; Relative humidity of $28.61 \%$ and photosynthetically active radiation of $977.16 \mu \mathrm{mol} \mathrm{S}^{-1} \mathrm{~m}^{-2}$.

The experimental design was completely randomized, in a uniform scheme composed of 10 evaluation times (from 8 am to $5 \mathrm{pm}$, with an interval of $1 \mathrm{~h}$ between evaluations) and three replications. 
Each replicate consisted of three evaluation plants, totaling nine seedlings, which were arranged on a double border.

The greenhouse in which the present work was carried out is orientated in the east-west direction, characterized by a cover with a 150 micron plastic film, with a right foot of $3.5 \mathrm{~m}$ in height and dimensions of $10 \mathrm{~m}$ in width and $20 \mathrm{~m}$ in length. The sowing was carried out on July 15, 2010 in black polyethylene pots with a capacity of $5 \mathrm{~L}$, spaced at $0.5 \mathrm{~m}$, containing typical dystrophic Red Latosol, with a clayey texture, deep and well drained. This type of soil is predominant in the region, which belongs to the Passo Fundo mapping unit (Embrapa, 2006). The sowing depth was $3 \mathrm{~cm}$, using 3 seeds per pot, and 30 days after sowing, the thinning was done, leaving 1 plant per pot.

During the conduction of the experiment, the water regime in the greenhouse was systematized in three irrigations daily through sprinklers in order to maintain pot capacity (PC). The PC was adopted as the water content retained by the soil after saturation and consequent gravity action, until the cessation of drainage (Souza et al., 2000).

The characteristics evaluated were: leaf temperature $\left({ }^{\circ} \mathrm{C}\right)$, photosynthetically active radiation $\left(\mu \mathrm{mol} \mathrm{S} \mathrm{S}^{-1} \mathrm{~m}^{-2}\right)$, stomatal resistance $\left(\mathrm{S} \mathrm{cm}^{-1}\right)$ and transpiration $(\mathrm{mmol}$ $\mathrm{H} 2 \mathrm{O} \mathrm{s}^{-1} \mathrm{~m}^{-2}$ ) over a day, with the use of a LI-1600 LICOR digital porometer. The measurements of the temperature and relative humidity of the air were determined within the greenhouse, using a thermohygrograph.

The evaluations were performed on $03 / 16 / 2011$, at 244 days after sowing, considered a typical day in agroclimatology, between 8:00 am and 5:00 pm, with a 60 minute interval, totaling 10 evaluations. This day was chosen because it presented the celestial vault in conditions of zero cloudiness, thus allowing the maximum effects of the meteorological elements on the growing environment and consequently on the characteristics analyzed, in order to contemplate the objectives of the work. This same methodology was used by Caron et al. (2014) when determining physiological relationships in seedlings of Bauhinia forficata Link (Brazilian orchid tree).

Data were submitted to statistical analysis using the "Statistical Analysis System" (SAS, 2003), with Pearson's correlation classified according to the degree of dependency proposed by Steel; Torrie (1980) as: very weak $(0-0.3)$, weak $(0.3-0.5)$, moderate $(0.5$ - 0.7), high (0.7 - 0.9) and very high (greater than $0.9)$. In order to verify the level of importance of the variables for leaf temperature prediction, stomatal resistance and transpiration, a polynomial regression analysis was performed to predict models of variables throughout the day. The Stepwise regression modeling selection procedure was used, and the selected model was evaluated for the conditioners of the regression based on the adjusted coefficient of determination ( $\left.\mathrm{R}^{2} \mathrm{aj}\right)$, coefficient of variation $(\mathrm{CV} ; \%)$, standard error of Estimation (Sxy), and analysis of the waste distribution.

\section{RESULTS}

From the Pearson correlation analysis, it was observed that stomatal resistance (SR) showed a very negative correlation with transpiration (TR) (-0.98) and high (-0.84) with the temperature (GT) of the greenhouse. In contrast, a high and positive correlation was reported for SR and relative humidity $(\mathrm{RH})$, the same level of dependence was found between TR and $\mathrm{RH}$, but with negative behavior (Table 1).

In Figure 1, we can observe the inverse behavior of the TR and SR curves, evidencing that the TR is reduced with the closure of the stomata. Quadratic behavior were observed for PAR and cubic behaviors were observed for LT, SR and TR.

According to Table 2, which presents the means of the parameters evaluated, we can verify that the values of TR were between 3.70 and $24.34 \mathrm{mmol} \mathrm{H}_{2} \mathrm{O}$ $\mathrm{s}^{-1} \mathrm{~m}^{-2}$, with the minimum value of TR found at 9:00 $\mathrm{am}$, and corresponding to the maximum SR.

When analyzing the means of the variables throughout the day, it can be observed that maximum values of the $\mathrm{LT}$, TR, and GT variables $\left(46.21^{\circ} \mathrm{C}, 24.34\right.$ mmol $\mathrm{H}_{2} \mathrm{O} \mathrm{s}^{-1} \mathrm{~m}^{-2}, 48.70^{\circ} \mathrm{C}$, respectively) were found at 3:00 pm.

The equations resulting from the Stepwise regression method at $5 \%$ of probability presented high adjusted coefficients of determination, being verified that they express the real variation of the variables analyzed, this motivated by the other tests applied in the analysis that selected the equations (Table 3). 
Table 1 - The existent Pearson correlation coefficients between the meteorological elements and the physiological variables in Aleurites fordii seedlings, where LT: leaf temperature $\left({ }^{\circ} \mathrm{C}\right)$; PAR: photosynthetically active solar radiation $\left.\mu \mathrm{mol} \mathrm{S}-1 \mathrm{~m}^{-2}\right)$; $\mathrm{SR}$ : stomatal resistance $\left(\mathrm{S} \mathrm{cm}^{-1}\right)$; TR: transpiration $\left(\mathrm{mmol} \mathrm{H}_{2} \mathrm{O} \mathrm{s}^{-1} \mathrm{~m}^{-2}\right)$; $\mathrm{RH}$ : relative humidity $(\%)$; GT: greenhouse temperature $\left({ }^{\circ} \mathrm{C}\right) .2014$.

Tabela 1 - Coeficientes de correlação de Pearson existente entre os elementos meteorológicos e as variáveis fisiológicas em mudas de Aleurites fordii, onde LT: temperatura da folha $\left({ }^{\circ} \mathrm{C}\right)$; PAR: radiação solar fotossinteticamente ativa ( $\left.\mu \mathrm{mol} \mathrm{S} \mathrm{S}^{-1} \mathrm{~m}^{-2}\right)$; SR: resistência estomática $\left(\mathrm{S} \mathrm{cm}^{-1}\right)$; TR: transpiração (mmol $\left.\mathrm{H}_{2} \mathrm{O} \mathrm{s}^{-1} \mathrm{~m}^{-2}\right)$; $\mathrm{RH}$ : umidade relativa (\%); GT: temperatura do ambiente protegido $\left({ }^{\circ} \mathrm{C}\right) .2014$.

\begin{tabular}{|c|c|c|c|c|c|c|}
\hline \multirow[t]{2}{*}{ Attribute } & \multicolumn{4}{|c|}{ Correlation coefficient } & \multirow[b]{2}{*}{ RH } & \multirow[b]{2}{*}{ GT } \\
\hline & LT & PAR & SR & TR & & \\
\hline $\mathrm{LT}$ & 1.0 & & & & & \\
\hline PAR & $0.31^{\mathrm{ns}}$ & 1.00 & & & & \\
\hline $\mathrm{SR}$ & $-0.89 * *$ & $0.01^{\mathrm{ns}}$ & 1.00 & & & \\
\hline TR & $0.93 * *$ & $0.04^{\mathrm{ns}}$ & $-0.98 * *$ & 1.00 & & \\
\hline RH & $-0.92 * *$ & $-0.53^{\mathrm{ns}}$ & $0.76 * *$ & $-0.79 * *$ & 1.00 & \\
\hline GT & $0.92 * *$ & $0.24^{\mathrm{ns}}$ & $-0.84 * *$ & $0.88 * *$ & $-0.90 * *$ & 1.00 \\
\hline
\end{tabular}

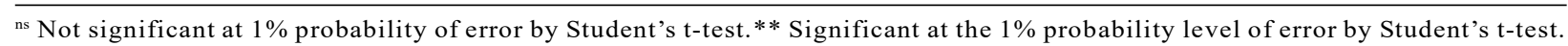
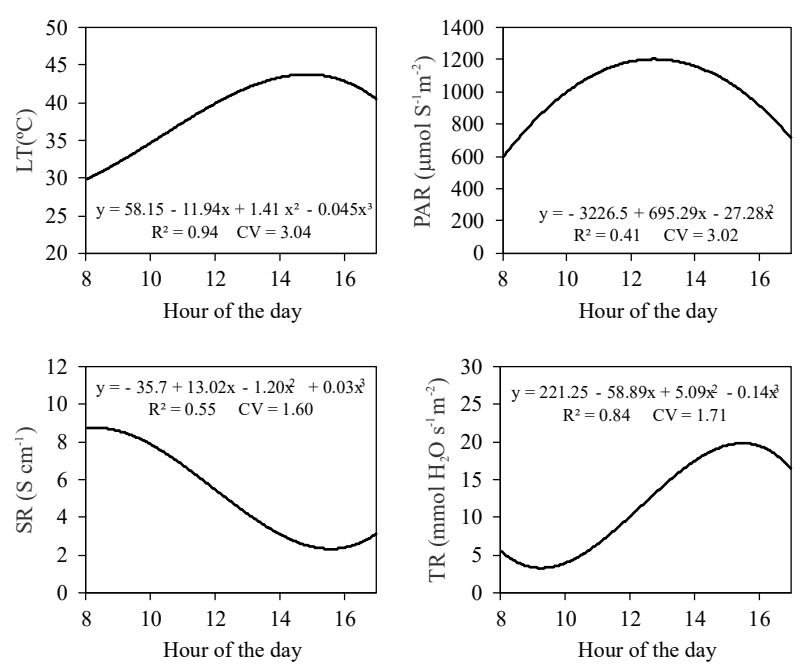

Figure 1 - Polynomial regression equations of leaf temperature (LT), photosynthetically active solar radiation (PAR), stomatal resistance (SR) and transpiration (TR) in Aleurites fordii seedlings. 2014.

Figura 1-Equações de regressão polinomial da temperatura da folha (LT), radiação solar fotossinteticamente ativa (PAR), resistência estomática (SR) etranspiração (TR) em mudas de Aleurites fordii. 2014.

\section{DISCUSSION}

The values found in Table 1 show that, where the levels of dependence were negative, as one variable increases, the other shows a decreasing trend, this result was also found by Souza et al. (2011), in a study with several forest species, $\mathrm{RH}$ reduced as TR increased.
The inverse behavior of the TR and SR curves can be considered as a defense of the plant, as verified by Rezende et al. (2011), working with Coffea arabica L. (coffee tree), reported that the SR of the non-irrigated treatment tended to increase, since the plant closed the stomata limiting water losses through transpiration.

According to Silva et al. (2008), water deficiency conditions are capable of affecting the stomatal apparatus by causing the stomata to close. In this same context, Yordanov et al. (2003) state that in a water deficit condition, the first defense adopted by the plant would be the restriction of the stomatal opening. Thus limiting photosynthesis, and consequently, the TR and avoiding loss of water content by the leaves (Machado et al., 2009).

According to Taiz; Zeiger (2013), plants with access to abundant water, even in high GT environments, are able to maintain the LT below $45^{\circ} \mathrm{C}$, through the evaporative cooling process. It was observed that only at $3 \mathrm{pm}$, LT exceeded this limit $\left(46.21^{\circ} \mathrm{C}\right)$, and the SR reported at the same time was $48.7^{\circ} \mathrm{C}$ (Table 2).

For the same authors, at a time close to noon, plants located in environments with high irradiance of direct sunlight, regardless of the type of metabolism (C3 or C4), may have their LT elevated from 4 to $5^{\circ} \mathrm{C}$ above air temperature, since low circulation of air in the greenhouse contributes to the reduction of the evaporative cooling process of the leaf. However, C3 plants are more affected by high temperatures, their quantum productivity reduced in this condition. 
Table 2 - Means of meteorological and physiological variables of Aleurites fordii seedlings at different times of day, where LT: leaf temperature $\left({ }^{\circ} \mathrm{C}\right)$; PAR: photosynthetically active solar radiation (ìmol $\mathrm{S}^{-1} \mathrm{~m}^{-2}$ ); SR: stomatal resistance $\left(\mathrm{S} \mathrm{cm}^{-1}\right)$; TR: transpiration ( $\left.\mathrm{mmol} \mathrm{H}_{2} \mathrm{O} \mathrm{s}^{-1} \mathrm{~m}^{-2}\right)$; RH: relative humidity $(\%)$; GT: greenhouse temperature $\left({ }^{\circ} \mathrm{C}\right)$. 2014.

Tabela 2 - Médias das variáveis meteorológicas e fisiológicas, em mudas de Aleurites fordii em diferentes horários do dia, onde LT: temperatura da folha $\left({ }^{\circ} \mathrm{C}\right)$; PAR: radiação solar fotossinteticamente ativa (ìmol $\left.\mathrm{S}^{-1} \mathrm{~m}^{-2}\right)$; SR: resistência estomática $\left(\mathrm{S} \mathrm{cm}^{-1}\right)$; TR: transpiração ( $\left.\mathrm{mmol} \mathrm{H}_{2} \mathrm{O} \mathrm{s}^{-1} \mathrm{~m}^{-2}\right)$; $\mathrm{RH}$ : umidade relativa (\%); GT: temperatura do ambiente protegido $\left({ }^{\circ} \mathrm{C}\right) .2014$.

\begin{tabular}{cccccc}
\hline Time & LT & PAR & SR & TR & GH \\
\hline 8 & 29.32 & 503.32 & 8.09 & 4.88 & 69.10 \\
9 & 32.72 & 952.18 & 9.60 & 3.70 & 41.00 \\
10 & 35.28 & 971.06 & 8.28 & 5.06 & 22.95 \\
11 & 37.06 & 1072.21 & 6.05 & 6.97 & 30.80 \\
12 & 39.90 & 1230.00 & 5.06 & 9.41 & 26.00 \\
13 & 40.77 & 1242.22 & 4.10 & 3.05 & 20.00 \\
14 & 42.99 & 1230.00 & 3.31 & 16.18 & 23.00 \\
15 & 46.21 & 969.88 & 2.48 & 24.34 & 15.00 \\
16 & 41.63 & 748.56 & 2.84 & 17.48 & 14.00 \\
17 & 40.46 & 852.20 & 2.82 & 16.27 & 24.00 \\
\hline
\end{tabular}

Table 3 - Regression equations by the Stepwise procedure, in physiological variables of Aleurites fordii seedlings, where SR: stomatal resistance $\left(\mathrm{S} \mathrm{cm}^{-1}\right)$, GT: greenhouse temperature $\left({ }^{\circ} \mathrm{C}\right)$, TR: transpiration $\left(\mathrm{mmol} \mathrm{H}_{2} \mathrm{O} \mathrm{s}^{-1} \mathrm{~m}^{-2}\right)$; LT: leaf temperature $\left({ }^{\circ} \mathrm{C}\right)$; RH: relative humidity (\%). 2014.

Tabela 3 - Equações de regressão pelo procedimento Stepwise, em variáveis fisiológicas de mudas de Aleurites fordii, onde $S R$ : resistência estomática $\left(\mathrm{S} \mathrm{cm}^{-1}\right)$, GT: temperatura do ambiente protegido $\left({ }^{\circ} \mathrm{C}\right)$, TR: transpiração $\left(\mathrm{mmol} \mathrm{H}_{2} \mathrm{O}\right.$ $\left.\mathrm{s}^{-1} \mathrm{~m}^{-2}\right)$; LT: temperatura da folha $\left({ }^{\circ} \mathrm{C}\right) ; \mathrm{RH}$ : umidade relativa (\%). 2014.

\begin{tabular}{lccc}
\hline Equation & $\mathrm{CV}^{*}$ & $\mathrm{R}^{2}$ aj. & Sxy \\
\hline $\mathrm{SR}=26.3993-0.5129 *(\mathrm{GT})$ & 0.8 & 0.93 & 0.029 \\
$\mathrm{TR}=-86.8065+1.1084 *(\mathrm{LT})+0.4863 *(\mathrm{RH})+1.0275 *(\mathrm{GT})$ & 3.3 & 0.94 & 0.042 \\
$\mathrm{LT}=18.3131+0.2806 *(\mathrm{TR})+0.4437 *(\mathrm{GT})$ & 2.2 & 0.96 & 0.065 \\
\hline
\end{tabular}

$* \mathrm{CV}=$ Coefficient of variation; $\mathrm{R}^{2} \mathrm{aj} .=$ Adjusted coefficient of determination; $\mathrm{Sxy}=\mathrm{Standard}$ error of estimation.

In general, SR decreases when an increase in GT is observed. This is corroborated by Silva (2007), who observed the phenomenon when working with Schinus terebinthifolius (Brazilian peppertree). The plant was allowed to close the stomata in order to save water during the hottest hours of the day. This may be justified by agreement with Larcher (2004), reporting that the stomata is the first organ of the plant to experience water deficiency.

In warmer temperatures, such as early in the morning, the highest SR rates are observed, which is the moment when there are low levels of gas exchange between the plants and the atmosphere. This result is in agreement with Machado et al. (2013) that, when working with Saccharum officinarum L. (sugarcane), verified that the assimilation of $\mathrm{CO}_{2}$ decreased in the nocturnal period, when the temperatures were low.

Rezende et al. (2011) found that stomatal opening is considered the main control mechanism in gas exchange by plants. Therefore, since stomata are structures responsible for regulating gas exchange, $\mathrm{CO}_{2}$ will influence the leaf mesophyll, under conditions of increase in stomatal conductance, leading to higher rates of $\mathrm{CO}_{2}$ assimilation (Shimazaki et al., 2007).

In relation to the highest values of $\mathrm{LT}, \mathrm{TR}$, and SR found at $3 \mathrm{pm}$, it can be seen that, when the highest temperature reached inside the environment where the plants were, the highest LT was also obtained, and consequently, the same ones to maintain their LT at adequate levels presented the highest TR indexes.

According to Cabrera (2002) and Gazolla-Neto (2013), high values of solar radiation can impair the quantum efficiency of photosynthesis, because when incident under the plant causes the destruction of the photosynthetic apparatus, thus generating a greater exposure of the leaves to the sun. This causes its temperature to rise, intensifying the TR and inducing the closure of the stomata. This occurs mainly in plants 
with C3 metabolism, as is the case of the Aleurites fordii species, since C4 plants have a higher photosynthetic rate under high luminous intensity and higher temperatures (Taiz and Zeiger, 2013).

These justifications reported in the literature corroborate with the results found in this paper and those reported by Hirayama et al. (2006), in which it was verified that LT was highly correlated with TR. In the same way, Table 1 shows a very high correlation between LT and TR (0.93).

Through the results found in this work, it was possible to identify a high relation between the meteorological elements and the studied physiological variables. Similar results were observed by Carneiro et al. (2008), working with physiological variables in eucalyptus seedlings, where they verified the existence of the correlation between stomatal resistance and meteorological variables: global solar radiation, water vapor pressure deficit and temperature.

According to the above, it is possible to notice that, the variables evaluated throughout the day influenced the physiological parameters. In the same way, it is observed that they were affected by being determined in a protected environment, where the evaporative demand of the air is fully satisfied, with smaller evapotranspiration peaks being verified, caused by the attenuation of the solar radiation flow and the velocity of the wind through the plastic film.

\section{CONCLUSION}

The physiological behavior of Aleurites fordii seedlings is affected by daylight hours. In general, the studied physiological variables are highly dependent on meteorological elements.

The temperature of the greenhouse and the relative humidity of the air are the meteorological elements that most influence the physiological behavior of the Aleurites fordii seedlings.

\section{REFERENCES}

Almeida IR, Anjos SD, Wrege MS. Zoneamento agroclimático da cultura do Tungue na Região Sul do Brasil. Pelotas: Embrapa Clima Temperado; 2012. (Documento, 358).

Bergonci JI, Bergamaschi H, Berlato MA, Santos AO. Potencial da água na folha como um indicador de déficit hídrico em milho. Pesquisa Agropecuária Brasileira. 2000;35(8):1531-40.

Brunini O, Cardoso M. Efeito do déficit hídrico no solo sobre o comportamento estomático e o potencial da água em mudas de seringueira. Pesquisa Agropecuária Brasileira. 1998;33(7):1053-60.

Cabrera HM. Respuestas ecofisiológicas de plantas em ecosistemas de zonas con clima mediterráneo y ambientes de alta montaña. Revista Chilena de História Natural. 2002;7:625-37.

Carneiro RLC, Ribeiro A, Huaman CAM, Leite FP, Sediyama GC, Neves JCL. Consumo de água em plantios de eucalipto: Parte 2 Modelagem da resistência estomática e estimativa da transpiração em tratamentos irrigados e não irrigados. Revista Árvore. 2008;32(1):11-8.

Caron BO, Perrando ER, Schmidt D, Manfron PA, Behling A, Elli EF et al. Relações fisiológicas em mudas de pata-de-vaca (Bauhinia forficata Link). Revista Brasileira de Plantas Medicinais. 2014;16(2):196-201.

Empresa Brasileira de Pesquisa Agropecuária Embrapa. Sistema Brasileiro de Classificação de Solos. $2^{\mathrm{a}}$.ed. Rio de Janeiro: Embrapa-SPI; 2006. $412 \mathrm{p}$.

Fagan EB, Medeiros SLP, Borcioni E, Luz GL, Simon J, Jasniewicz LR et al. Influência de intervalos entre irrigações na fisiologia e produção de meloeiro sob sistema hidropônico. Revista Brasileira Agrociência. 2005;11(4):429-36.

Gabriel LF, Streck NA, Uhlmann LO, Silva MR, Silva SD. Mudança climática e seus efeitos na cultura da mandioca. Revista Brasileira de Engenharia Agrícola e Ambiental. 2014;18(1):90-8.

Gazolla-Neto A, Aumonde TZ, Pedó T, Olsen D, Villela FA. Ação de níveis de luminosidade sobre o crescimento de plantas de maria-pretinha (Solanum americanum Mill.). Revista Brasileira Biociência. 2013;11(1):88-92.

Golfetto DC, Zan RA, Barbosa NV, Brondani FMM, Meneguetti DUO. Estudo e aplicação da amêndoa do tungue (Aleurites fordii) na produção do biodiesel. Revista Científica da 
Faculdade de Educação e Meio Ambiente. 2011;2(1):55-68.

Hirayama M, Wada Y, Nemoto H. Estimation of drought tolerance based on leaf temperature in upland rice breeding. Breeding Science. 2006;56(1):47-54.

Larcher W. Ecofisiologia vegetal. São Carlos: Rima; 2004. 531p.

Machado DFSP, Lagôa AMMA, Ribeiro RV, Marchiori PER, Machado RC, Machado EC. Baixa temperatura noturna e deficiência hídrica na fotossíntese de cana-de-açúcar. Pesquisa Agropecuária Brasileira. 2013;48(5):487-95.

Machado RS, Ribeiro RV, Marchiori PER, Machado DFSP, Machado EC, Landell MGA. Respostas biométricas e fisiológicas ao déficit hídrico em cana-de-açúcar em diferentes fases fenológicas. Pesquisa Agropecuária Brasileira. 2009;44(12):1575-82.

Maluf JRT. Nova classificação climática do Estado do Rio Grande do Sul. Revista Brasileira de Agrometeorologia. 2000;8(1):141-50.

Melo AS, Suassuna JF, Fernandes PD, Brito MEB, Suassuna AF, Aguiar Netto AO. Crescimento vegetativo, resistência estomática, eficiência fotossintética e rendimento do fruto da melancieira em diferentes níveis de água. Acta Scientiarum Agronomy. 2010;32(1):73-9.

Rezende FC, Caldas ALD, Scalco MS, Faria MA, Silva EL. Resistência estomática e taxa de transpiração do cafeeiro em função da densidade de plantio e da irrigação. In: Anais do $7^{\circ}$ Simpósio de Pesquisa dos Cafés do Brasil. 22 a 25 de ago. de 2011. Araxá: 2011.

Ribas F. Respuesta fisiológica de un cultivo de melón (Cucumis melo L.) a distintas dosis de riego. Investigation Agronomy: Produccion Y Proteccion Vegetal. 2000;15(3):196-212.

SAS Learning Edition. Getting started with the SAS Learning Edition. Cary: 2003. 200p.

Shimazaki K, Doi M, Assmann SM, Kinoshita T. Light regulation of stomatal movement. Annual Review of Plant Biology. 2007;58(1):219-47.
Silva MBR, Fernandes PD, Dantas Neto J, Nery AR, Rodrigues LN, Viégas RA. Crescimento e produção do pinhão-manso irrigado com água residuária sob condições de estresse hídrico. Revista Brasileira de Engenharia Agrícola e Ambiental. 2011;15(6):621-9.

Silva MAV. Resposta estomática e produção de matéria seca em plantas jovens de aroeira submetidas a diferentes regimes hídricos. Revista Árvore. 2008;32(2):335-44.

Silva MAV. Avaliação fisiológica da Aroeira (Schinus terebinthifolius Raddi) sob déficit hídrico com vista para o reflorestamento [dissertação]. Recife: Universidade Federal de Pernambuco; 2007. 84p.

Souza CD, Fernandes DP, Barroso MR, Portes TA. Transpiração de espécies típica do cerrado medida por transpirômetro de equilíbrio e porômetro. Cerne. 2011;17(4):509-15.

Souza CC, Oliveira FA, Silva IF, Amorim Neto MS. Avaliação de métodos de determinação de água disponível e manejo de irrigação em terra roxa sob cultivo de algodoeiro herbáceo. Revista Brasileira de Engenharia Agrícola e Ambiental. 2000;4(3):338-42.

Steel RGR, Torrie JH. Principles and procedures of statistics: A biometrical approach. $2^{\text {nd }}$.ed. London: McGraw-Hill, 1980. 666p.

Taiz L, Zeiger E. Fisiologia vegetal. $5^{\text {a }}$.ed. Porto Alegre: Artmed; 2013.918p.

Tonello KC, Teixeira Filho J. Transpiração e condutância estomática de Eucalyptus $s p$ em resposta à radiação global e diferentes condições hídricas. Irriga. 2013;18(4):607-23.

Vellame LM, Coelho RD, Tolentino JB. Transpiração de plantas jovens de laranjeira 'valência' sob porta-enxerto limão 'cravo' e citrumelo 'swingle' em dois tipos de solo. Revista Brasileira Fruticultura. 2012;34(1):24-32.

Yordanov I, Velikova V, Tsonev T. Plant responses to drought and stress tolerance. Bulgarian Journal of Plant Physiology. 2003; Special issue:187-206. 